\title{
OPTIMIZING OIL PRODUCTION AT THE GATHERING STATION BY MAINTAINING THE OIL STOCK TANK / INTERFACE LEVEL IN THE WASH TANK USING THE ROC SYSTEM
}

\author{
(OPTIMASI PRODUKSI MINYAK PADA GATHERING STATION DENGAN \\ MENJAGA OIL STOCK TANK / INTERFACE LEVEL PADA WASH TANK \\ DENGAN MENGGUNAKAN SYSTEM ROC)
}

\author{
Richa Melysa $^{{ }^{*}}$, Zainul Fiqri ${ }^{2}$, Ali Musnal ${ }^{1}$ \\ ${ }^{1}$ Jurusan Teknik Perminyakan, Fakultas Teknik, Universitas Islam Riau \\ ${ }^{2} P T$. Chevron Pacific Indonesia (CPI) \\ *Corresponding author : richamelysa@eng.uir.ac.id
}

\begin{abstract}
The problem that often occurs at the Gathering Station is the problem of unstable production, this is due to the less than optimal control of the fluid level in the wash tank, so special actions are needed such as controlling the fluid level in the storage tank, monitoring pressure, monitoring temperature and others what needs to be done to have a positive effect on oil production at the gathering station. Research conducted on the problem of controlling the fluid level in the wash tank, where manual control is not effective and efficient, it is necessary to change from manual to automatic processes with the ROC (Remote Operation Control) system, these changes are expected to maintain the interface and oil stock tank according to a predetermined set point. Based on research conducted optimization of production using the ROC system carried out on $G S X$ gave an increase in production of $0.78 \%$ in wash tank 1, 1.24\% in wash tank 3, and $41.50 \%$ in wash tank 4. With the implementation of the ROC system we must maintain interface and oil stock tank according to the set point that has been determined and where the amount of oil production per day at the gathering station greatly affects the oil stock tank..
\end{abstract}

Keyword: Interface, Oil Stock Tank, Remote Operation Control, Wash Tank

\begin{abstract}
ABSTRAK
Permasalahan yang sering terjadi pada Gathering Station adalah masalah produksi yang tidak stabil, hal ini disebabkan oleh pengontrolan level fluida di wash tank yang kurang maksimal untuk itu perlu dilakukan tindakan khusus seperti pengendalian level fluida di tangki penampung, pengawasan terhadap tekanan, pengawasan terhadap temperatur dan lainnya yang perlu dilakukan untuk dapat berpengaruh positif terhadap produksi minyak di gathering station. Penelitian yang dilakukan pada permasalahan pengendalian terhadap level fluida di wash tank, dimana pengendalian secara manual tidak efektif dan efisien, untuk itu perlu dilakukan perubahan dari proses manual ke otomatis dengan system ROC (Remote Operation Control), perubahan yang dilakukan ini diharapkan dapat menjaga interface dan oil stock tank sesuai dengan set point yang telah ditentukan. Berdasarkan penelitian yang dilakukan optimasi produksi dengan menggunakan
\end{abstract}


sistim ROC yang di lakukan pada GS X memberikan peningkatan produksi sebesar $0.78 \%$ di wash tank 1, 1.24\% di wash tank 3, dan $41.50 \%$ pada wash tank 4. Dengan diterapkannya sistim ROC kita harus menjaga interface dan oil stock tank sesuai dengan set point yang telah ditentukan dan dimana besarnya produksi minyak per-hari di gathering station sangat berpengaruh terhadap oil stock tank.

Kata Kunci: Interface, Oil Stock Tank, Remote Operation Control, Wash Tank

\section{PENDAHULUAN}

Untuk menjaga stabilitas produksi di gathering station perlu dilakukan tindakan khusus seperti pengendalian level fluida di tangka penampung, pengawasan terhadap tekanan, pengawasan terhadap temperatur dan lainnya yang perlu dilakukan untuk dapat berpengaruh positif terhadap produksi minyak di gathering station. Adapun cara pengendalian (monitoring) terhadap ketiga hal tersebut adalah dilakukan oleh operator gathering station dengan cara datang langsung kelapangan dan mencatat secara manual dari alat pengukur yang terpasang dan melakukan tindakan manual untuk membuka dan menutup untuk mengendalikan level tangki, kemudian pengendalian dilakukan dengan cara monitoring menggunakan instrument yang dihubungkan dengan cotroller dan final control element yang melakukan pengendalian secara otomatis.

Wash Tank merupakan tangki yang berguna untuk penampungan sementara fluida cair (liquid) yang berasal dari gas boot. Fluida cair yang memasuki wash tank terdiri dari campuran antara minyak mentah dan air. Di wash tank terjadi proses pemisahan antara minyak mentah dan air. Wash tank ini merupakan tangki yang paling besar dibanding dengan tangki - tangki pengolahan lain yang ada di gathering station, diameternya adalah sekitar $85 \mathrm{ft}$ hingga $90 \mathrm{ft}$, dan tingginya adalah sekitar $35 \mathrm{ft}$ hingga $40 \mathrm{ft}$. Level normal dalam proses pemisahan adalah $36 \mathrm{ft}$, dimana level $1 \mathrm{ft}-29 \mathrm{ft}$ adalah level air, sedangkan di level $29 \mathrm{ft}-36 \mathrm{ft}$ adalah level minyak. Level $1 \mathrm{ft}$ - $29 \mathrm{ft}$ disebut sebagai interface level, dimana level air diharapkan berada pada level 29 dan ketebalan minyak / oil stock tank $7 \mathrm{ft}$ didalam wash tank tersebut.

Penulis meneliti permasalahan pengendalian terhadap level fluida di wash tank, dimana pengendalian secara manual adalah tidak efektif dan efisien, untuk itu perlu dilakukan perubahan dari proses manual ke otomatis dengan system ROC (Remote Operation Control), perubahan yang dilakukan ini diharapkan dapat menjaga interface dan oil stock tank sesuai dengan set point yang telah ditentukan dan dimana besarnya produksi minyak per-hari di gathering station sangat berpengaruh terhadap oil stock tank agar minyak yang dipompakan ke shipping line memiliki BS\&W dibawah $1 \%$ dan memiliki temperatur $130^{\circ} \mathrm{F}-150^{\circ} \mathrm{F}$, untuk medapatkan nilai ini, kita harus menjaga interface dan oil stock tank sesuai dengan set point yang telah ditentukan dan dimana besarnya produksi minyak per-hari di gathering station sangat berpengaruh terhadap oil stock tank. 
ROC merupakan otak dari sistem pengontrolan interface level, dimana tipe yang digunakan adalah ROC 809 , SOV atau solenoid valve berfungsi untuk switching antara mode pengontrolan yang menggunakan ROC dengan LIC (Level Indicator Controller), akan tetapi pada kondisi yang normal, mode pengontrolan yang digunakan adalah menggunakan ROC, I/P adalah tranduser yang berfungsi untuk merubah sinyal standar dari satu besaran ke besaran lainnya, jadi kalau dilihat dari symbol huruf yang digunakan, merupakan konversi dari arus ke tekanan (Mulyadi, A., 2007)

Penelitian ini akan lebih fokus pada proses yang terjadi pada wash tank. Pada pipa keluaran air dari wash tank dipasang valve-valve untuk menjaga interface berada pada set point yang telah ditentukan. Jika level interface lebih tinggi dari set point, maka valve akan membuka sesuai dengan perintah dari controller. Namun, jika level interface turun, valve akan menutup. Valve yang dipasang di pipa yang menuju clarifier tank ini menggunakan control valve yang dilengkapi dengan by pass valve untuk keamanan.

Control valve ini berperan sebagai final control elemen dari sistem pengendalian otomatis seperti yang sudah dipaparkan pada alinea pertama di atas. Sensor yang dapat mengukur interface akan mengirim data ke controller (Remote Operating Controller), data tersebut akan diolah dan kemudian hasilnya berupa "perintah" yang dikirim ke control valve. Namun, terdapat permasalahan yang terjadi di salah satu GS PT. Chevron Pacific Indonesia, dimana reaksi control valve tersebut sangat lambat dalam menjalankan perintah dari controller. Hal ini akan sangat berpengaruh pada proses pengelolaan minyak bumi.

Dengan melakukan penelitian di tempat penampungan minyak (GS) peneliti dapat mengetahui dan mengerti tentang pentingnya mengontrol level dari fluida di wash tank (interface level) dalam menjaga produksi minyak di sebuah gathering station dengan sistim remote operation control (ROC) dan dapat mengaplikasikan ilmu yang didapat sementara dibangku kuliah dan mengaplikasikan di lapangan

\section{METODE PENELITIAN}

Penelitan dilaksanakan dengan metode error dan survey lapangan. Dimana data-data yang diperoleh dilakukan pengolahan data dengan melakukan perbandingan monitoring level fluida (level interface) dengan data yang diperoleh langsung survey kelapangan secara manual. Data yang terbaca secara remote control akan terbaca di sebuah layar atau tampilan berupa HMI dimana sistim pengontrolan yang dialukan berupa level yang terbaca oleh radar akan dikirim ke ROC (Remote Operation Controller) untuk kemudian ditampilkan pada HMI. ROC merupakan remote terminal unit yang memiliki fungsi sama dengan PLC, seperti untuk mengontrol dan memonitor perangkat di lapangan.

Selain menggunakan radar, LIT juga digunakan untuk mengukur ketinggian air di wash tank. Data level yang terbaca oleh LIT dikirimkan ke PLC untuk ditampilkan di HMI. ROC dan PLC juga digunakan untuk mengontrol level pada air untuk menjaga ketebalan minyak di dalam 
wash tank. Melalui SOV Switch mode pengontrolan dapat dipilih menggunakan ROC atau LIT.

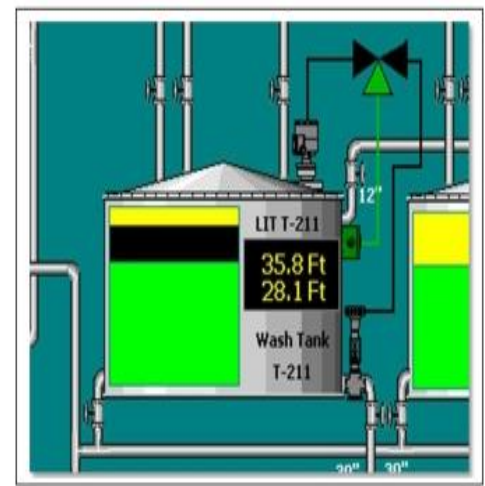

Gambar 1 Tampilan Wash tank di HMI (Chevron)

\section{Automatic Controller}

Pada prinsipnya pengendalian otomatis sama dengan pengendalian manual. Pada pengendalian otomatis, peranan dari operator digantikan oleh suatu alat yang disebut pengendali (controller). Jadi yang bertugas menambah dan mengurangi bukaan valve tidak lagi dikerjakan oleh operator tetapi atas perintah controller, operator hanya bertugas memberikan harga ke controller (set value / set point $=\mathrm{SV} / \mathrm{SP})$. Oleh karena itu pengendalian otomatis pada valve harus dilengkapi dengan actuator sehingga unit valve tersebut disebut dengan control valve. Sehingga apabila terjadi ketidak sesuai harga yang diberikan operator terhadap controller (SV), maka atas perintah controller akan membuka atau menutup sesuai dengan kondisi operasi yang sedang berjalan (process variable $=\mathrm{PV})$. Remote operations controller (ROC) pada dasarnya dibuat untuk pengukuran aliran gas pada gas alam, dimana desain pengukurannya menggunakan regulasi dari American Gas Association (AGA) dan beberapa standar lainnya. Tapi karena kebutuhan pasar untuk integrasi pengontrolan meningkat, jadi ROC mulai dikembangkan untuk semua pengontrolan (aliran, level, volume, dan lainnya). Jadi ROC pada instrumentasi berfungsi sebagai controller, yang bertugas untuk mengolah input sesuai dengan SP yang diinginkan operator, dan memberikan feedback ke output untuk koreksi error yang terjadi.

Inovasi yang tinggi dan bisa melakukan berbagai fungsi pengontrolan merupakan karakteristik dari ROC dengan integrasi koneksi backplane ke Central Processor Unit (CPU), modul power input, modul komunikasi, dan modul I/O. ROC mempunyai 9 slot modul, dengan susunan 3 modul pada masing-masing kolom. ROC bisa mendukung beberapa jenis komunikasi protocol yaitu, ROC plus, Modbus, Modbus TCP/IP, Modbus encapsulated pada Transmission Control Protocol / Internet Protocol (TCP/IP), dan Modbus dengan Electronic Flow Measurement (EFM) extentions.

\section{HASIL DAN PEMBAHASAN}

Wash tank di GS X merupakan tangki yang paling besar dibanding dengan tangki-tangki pengolahan lain yang ada di gathering station $\mathrm{X}$ itu sendiri, diameternya adalah sekitar $85 \mathrm{ft}$ hingga $90 \mathrm{ft}$, dan tingginya adalah sekitar $35 \mathrm{ft}$ hingga $40 \mathrm{ft}$. Level normal dalam proses pemisahan adalah $36 \mathrm{ft}$, dimana level $1 \mathrm{ft}-29 \mathrm{ft}$ adalah level air, sedangkan di level 29 $\mathrm{ft}-36 \mathrm{ft}$ adalah leve lminyak. Level $1 \mathrm{ft}$ - $29 \mathrm{ft}$ disebut sebagai interface level, dimana level air diharapkan 
berada pada level 29 dan ketebalan minyak / oil stock tank $7 \mathrm{ft}$ didalam wash tank tersebut. Untuk menjaga interface level tersebut diterapkan sistim pengontrolan secara otomatis yang disebut dengan ROC.

Table 1. Data produksi GS X wash tank1, 3 dan 4 sebelum ROC

Sumber chevron data (jan-march) 2019

\begin{tabular}{cccccccccc}
\hline & \multicolumn{3}{c}{ Wash Tank 1 } & \multicolumn{3}{c}{ Wash Tank 3 } & \multicolumn{3}{c}{ Wash Tank 4 } \\
\cline { 2 - 10 } Parameter & $\begin{array}{c}\text { Jan- } \\
19\end{array}$ & $\begin{array}{c}\text { Feb- } \\
19\end{array}$ & $\begin{array}{c}\text { Mar- } \\
19\end{array}$ & $\begin{array}{c}\text { Jan- } \\
19\end{array}$ & $\begin{array}{c}\text { Feb- } \\
19\end{array}$ & $\begin{array}{c}\text { Mar- } \\
19\end{array}$ & $\begin{array}{c}\text { Jan- } \\
19\end{array}$ & $\begin{array}{c}\text { Feb- } \\
19\end{array}$ & $\begin{array}{c}\text { Mar- } \\
19\end{array}$ \\
\hline $\begin{array}{c}\text { Top Level } \\
\text { (ft) }\end{array}$ & 35,78 & 35,66 & 35,74 & 25,51 & 25,53 & 25,35 & 26,16 & 25,85 & 25,81 \\
\hline $\begin{array}{c}\text { Interface } \\
\text { (ft) }\end{array}$ & 28,80 & 28,82 & 28,89 & 19,58 & 19,56 & 19,41 & 20,23 & 19,93 & 19,85 \\
\hline $\begin{array}{c}\text { Stock } \\
\text { Tank (ft) }\end{array}$ & 6,99 & 6,84 & 6,85 & 5,93 & 5,97 & 5,94 & 5,93 & 5,92 & 5,96 \\
\hline
\end{tabular}

Tabel 2 Data produksi GS X wash tank 1, 3 dan 4 sesudah ROC Sumber chevron data (juli-Aug) 2019

\begin{tabular}{cccccccccc}
\hline & \multicolumn{3}{c}{ Wash Tank 1 } & \multicolumn{3}{c}{ Wash Tank 3 } & \multicolumn{3}{c}{ Wash Tank 4 } \\
\cline { 2 - 10 } Parameter & Jul-19 & $\begin{array}{c}\text { Agt- } \\
19\end{array}$ & $\begin{array}{c}\text { Sep- } \\
19\end{array}$ & Jul-19 & $\begin{array}{c}\text { Agt- } \\
19\end{array}$ & $\begin{array}{c}\text { Sep- } \\
19\end{array}$ & Jul-19 & $\begin{array}{c}\text { Agt- } \\
19\end{array}$ & $\begin{array}{c}\text { Sep- } \\
19\end{array}$ \\
\hline $\begin{array}{c}\text { Top Level } \\
\text { (ft) }\end{array}$ & 35,78 & 35,66 & 35,74 & 35,78 & 35,66 & 35,74 & 35,78 & 35,66 & 35,74 \\
\hline $\begin{array}{c}\text { Interface } \\
\text { (ft) }\end{array}$ & 28,75 & 28,64 & 28,71 & 28,75 & 28,64 & 28,71 & 28,75 & 28,64 & 28,71 \\
\hline $\begin{array}{c}\text { Stock } \\
\text { Tank (ft) }\end{array}$ & 7,03 & 7,02 & 7,03 & 7,03 & 7,02 & 7,03 & 7,03 & 7,02 & 7,03 \\
\hline
\end{tabular}

\section{Optimasi Produksi Gathering Station X}

Optimasi produksi minyak yang dilakukan pada gathering station $\mathrm{X}$ berdasarkan adanya kendala-kendala yang dihadapi dalam memonitor level fluida yang terdapat pada gathering station X (wash tank 1, wash tank 3 dan wash tank 4), metode ROC adalah solusi yang tepat diterapkan untuk mengontrol level fluida yang terdapat pada masing-masing wash tank.

Optimasi yang terjadi dilakukan dapat dilihat pada seberapa besar perbedaan level fluida yang terbentuk (top level - interface) dan retention time yang terbentuk sebelum dan sesudah sistim ROC di terapkan pada operasional gathering station $\mathrm{X}$, untuk lebih jelasnya dapat dilihat pada perhitungan dibawah ini:

\section{Penentuan stock tank oil}

Penentuan stock tank oil adalah dilakukan dengan melakukan pengurangan dari data top level fluida terhadap interface level fluida yang terbaca, dimana stock yang dihitung adalah pada saat sebelum diberlakukannya sistim ROC dan sesudah diberlakukannya sistim ROC. Sebelum diterapkan sistim ROC data yang dilakukan penelitian adalah dari bulan januari 2018 s/d maret 2019 dan untuk setelah diterapkan sistim ROC data yang 
dilakukan penelitian dari bulan juli 2019 s/d September 2019.

Dari hasil perhitungan total stock oil yang terdapat pada masing-masing wash tank, dapat ditentukan perbedaan stock tank sebelum dan sesudah sistim ROC seperti yang terlihat pada grafik dibawah ini berdasarkan pengurangan stock tank sesudah ROC dengan sebelum ROC.

Tabel 3 Total oil stock tank sebelum sistim ROC

\begin{tabular}{cccc}
\hline & W 1 & W 3 & W 4 \\
DATE & $\begin{array}{c}\text { Total } \\
\text { Stock } \\
\text { tank }\end{array}$ & $\begin{array}{c}\text { Total } \\
\text { Stock } \\
\text { tank }\end{array}$ & $\begin{array}{c}\text { Total } \\
\text { Stock } \\
\text { tank }\end{array}$ \\
\hline Jan-19 & 216,59 & 183,82 & 183,91 \\
& & & \\
Feb-19 & 191,50 & 167,26 & 165,73 \\
& & & \\
Mar-19 & 205,50 & 178,14 & 178,74 \\
\hline
\end{tabular}

Dapat disimpulkan bahwa pengaruh fine tuning mampu meningkatkan produksi crude oil pada wash tank 1 , wash tank 3 , dan wash tank 4. Bisa dilihat persentase peningkatan produksi pada wash tank 1, wash tank 3, dan wash tank 4 antara sebelum dengan setelah fine tunning. Pada wash tank $10.78 \%$, wash tank 3 $1.24 \%$, dan pada wash tank $41.50 \%$.

Tabel 4 Total oil stock tank sesudah sistim ROC

\begin{tabular}{cccc}
\hline DATE & W 1 & W 3 & W 4 \\
& $\begin{array}{c}\text { Total } \\
\text { Stock } \\
\text { tank }\end{array}$ & $\begin{array}{c}\text { Total } \\
\text { Stock } \\
\text { tank }\end{array}$ & $\begin{array}{c}\text { Total } \\
\text { Stock } \\
\text { tank }\end{array}$ \\
\hline Jul-19 & 217,98 & 185,65 & 185,11 \\
& & & \\
Agu-19 & 196,62 & 168,55 & 166,96 \\
& & & \\
Sep-19 & 210,90 & 180,64 & 180,25 \\
\hline
\end{tabular}

\section{Penentuan retention time water} dan oil

Tujuan dilakukannya perhitungan terhadap retention time adalah untuk membedakan berapa lama waktu yang dibutuhkan oleh fluida pada saat fluida masuk kedalam wash tank dan mengalami proses di wash tank kemudian keluar kembali. Waktu sebelum dan sesudah sistim ROC itu diterapkan.

\section{Peningkatan Produksi}

Setelah dilakukan fine tuning, maka diharapkan produksi akan meningkat. Data untuk peningkatan produksi bisa dilihat pada tabel dibawah ini:

Tabel 5 Total kenaikan produksi setelah ROC

DATE Kenaikan produksi

\begin{tabular}{cc}
\hline Jan-19/Jul-19 & $0,78 \%$ \\
Feb-19/Aug-19 & $1,24 \%$ \\
Mar-19/Sep-19 & $1,50 \%$ \\
\hline
\end{tabular}




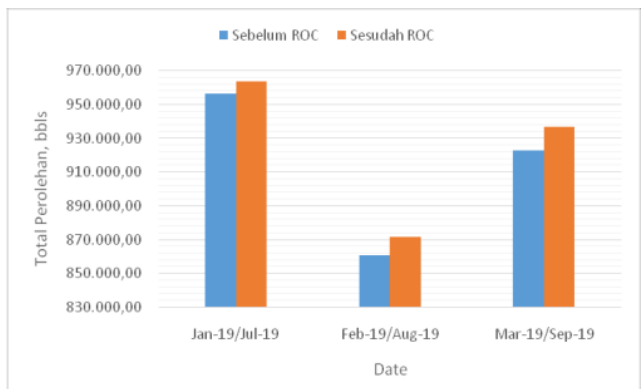

Grafik 1 Peningkatan perolehan produksi minyak

\section{Pengaruh ROC Terhadap Pengontrolan Valve Pada Interface Level}

Jika fine tunning tidak tepat, maka ROC bisa membuat bukaaan control valve dengan jarak yang terlalu jauh, bisa membuat menutup $0 \%$ dan membuka $100 \%$, hal ini sangat buruk terhadap proses oil separation.

Gambar 1 Sebelum dilakukan fine tunning

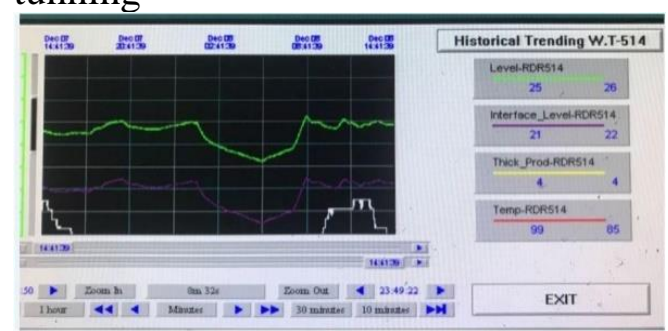

Setelah dilakukan fine tunning, kinerja control valve lebih ringan. Dan hasil bukaan control valve berada di $45 \%$ - 58\% dengan laju alir 270.00 Bbls perhari

Gambar 2 Setelah dilakukan fine tunning

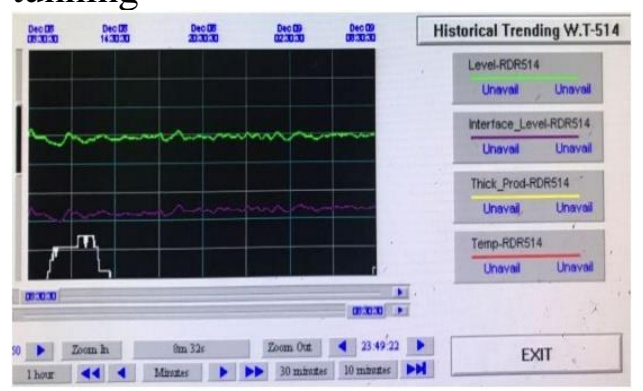

Selain dari fine tunning, yang menyebabkan terjadinya low respon terhadap pengontrolan interface di wash tank adalah keakurasian dari control valve tersebut. Bisa saja control valve sudah mengalami kebocoran atau kerusakan yang lainnya. Untuk menjaga keakurasian tersebut, control valve selalu dilakukan pengecekan / kalibrasi secara berkala oleh pihak maintenance.

Gambar 3 Interface setelah dilakukan fine tunning

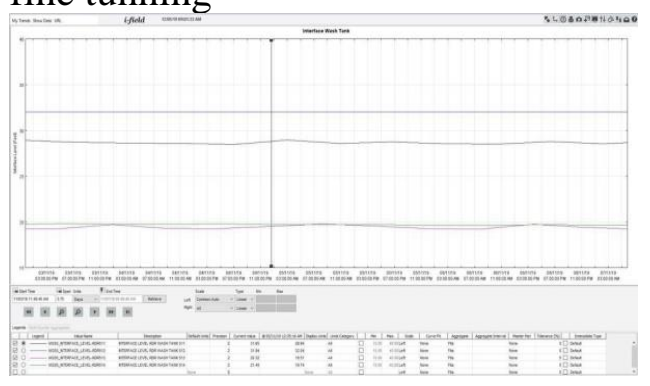

\section{Perbandingan ROC Terhadap Manual Kontrol}

Dengan melakukan perhitungan antara pengontrolan interface level baik secara manual dan secara sistim ROC dapat dilihat perubahan yang terjadi pada interface yang terbentuk didalam wash tank, baik itu wash tank 1 , wash tank 3 dan wash tank 4 yaitu terjadi pada adanya penambahan pada total stock tank pada masing-masing wash tank seperti yang terlihat pada table dibawah ini.

Tabel 6 Perbandingan sistim ROC terhadap manual control di wash tank 1

\begin{tabular}{cc}
\hline DATE & $\begin{array}{c}\text { Penambahan } \\
\text { Perolehan, bbls }\end{array}$ \\
\hline Jul-19 & 1563,75 \\
Aug-19 & 5760 \\
Sep-19 & 6075,5 \\
\hline
\end{tabular}

Tabel 7 Perbandingan sistim ROC terhadap manual control di wash tank 3 


\begin{tabular}{cc}
\hline DATE & $\begin{array}{c}\text { Penambahan } \\
\text { Perolehan, bbls }\end{array}$ \\
\hline Jul-19 & 3546,54 \\
Aug-19 & 2500,02 \\
Sep-19 & 4845,00 \\
\hline
\end{tabular}

Tabel 8 Perbandingan sistim ROC terhadap manual control di wash tank 4

\begin{tabular}{lc} 
DATE & $\begin{array}{c}\text { Penambahan } \\
\text { Perolehan, bbls }\end{array}$ \\
\hline Jul-19 & 2325,60 \\
Aug-19 & 2383,74 \\
Sep-19 & 2926,38 \\
\hline Dari ketiga tabel diatas dapat \\
dilihat pada bulan juli-sep 2019 \\
penambahan perolehan minyak terus \\
mengalami peningkatan, dengan \\
demikian selama tiga bulan \\
dibandingkan dengan secara manual \\
sisitim ROC memberikan \\
keekonomian yang lebih baik dan \\
efesien dan sisitim ROC tetap \\
dijalankan di wash ketiga wash tank \\
tersebut.
\end{tabular}

\section{KESIMPULAN}

Dari hasil penelitian yang dilakukan disumur minyak lapangan $\mathrm{Z}$ dapat di ambil beberapa kesimpulan sebagai berkut:

1. Optimasi produksi dengan menggunakan sistim ROC yang di lakukan pada GS X memberikan peningkatan produksi sebesar $0.78 \%$ di wash tank $1,1.24 \%$ di wash tank 3 , dan $41.50 \%$ pada wash tank 4. Dengan diterapkannya sistim ROC memberikan pengaruh positif terhadap pengontrolan valve, Penyebab terjadinya respon yang lama pada pengontrolan interface level di wash tank dikarenakan oleh setting tunning yang kurang tepat dan kerusakan yang terjadi pada valve itu sendiri.

2. Dengan melakukan perbandingan antara manual control dengan sistim ROC, sistim ROC memberikan dampak yang baik dalam pengontrolan interface level, yang dilihat dari adanya peningkatan perolehan produksi minyak dan proses oil separation yang baik.

\section{SARAN}

1. Sistem ROC sangat efektif digunakan untuk mengontrol kinerja valve - valve untuk meningkatkan ketepatan dalam pembacaan interface level dalam meningkatkan produksi minyak di gathering station.

2. Untuk peneliti selanjutnya disarankan meneliti tentang laju alir dan karakteristik proses di gathering station untuk proses fine tunning dari masing- masing gathering station.

\section{DAFTAR PUSTAKA}

Abdel-Aal, H. K., Zohdy, K., \& Abdelkreem, M. 2018. Waste Management in Crude oil Processing : Crude oil Dehydration and Desalting. International Journal of Waste Rosources.

Balakhrisna, T., Ghosh, S., Das, G., and Das, P.K., 2009. Oil-water flows through sudden contraction and expansion in a horizontal pipe - Phase distribution and pressure drop

Devold, H. 2006. Oil and Gas Production Handbook. Oslo: ABB. 
Iskandar, Z. 2003. Diktat Kuliah Proses Pengolahan Lapangan Fakultas Teknik Jurusan Teknin Perminyakan. Pekanbaru: Universitas Islam Riau.

Manning, F., \& Richard, E. 1995. Oilfield Processing Volume Two: Crude oil.

Manning, F.S., and Richard E.T., 1995, Oilfield Processing Volume Two: Crude oil, PennWell Books, Oklahoma.

N., Wayth, H., \& T.J Wiliam, A. 2001. Encyclopedic Handbook of Emulsion Technology. J. Sjoblom.

Oklahoma: Penn Well Books.

O\&TC. 2012. Production Operation Modul 6B. PT Chevron Pacific Indonesia. O. Urdahl,

PT. Chevron Pacific Indonesia, Production Operation, 2005, Modul 3A,3B O \& TC- HR Learning \& Development. Jakarta
PT. Chevron Pacific Indonesia, Production Operation, 2005, Modul 4A,4B O \& TC- HR Learning \& Development. Jakarta

PT. Caltex Pacific Indonesia, Production Operation, 2005, Modul 5, O \& TC HR Learning \& Development. Jakarta

Ronningsen, H.P. 1992. Water in Crude Oil Emulsions from the Norwegian Continental Shelf 7. Interfacial Pressure \& Emulsion Stability. Coll. Int. Sci. 66: 55-62.

Speight, James G. 2007. The Chemistry and Technology of Petroleum: 4th ed.

Sullivan, Andrew P. \& Peter K. Kilpatrick. 2002. The Effect of Inorganic Solid Particles on Water \&Crude Oil Emulsion Stability. Ind. Eng. Chem. Res. 41, 3389-3404. 